\title{
Changes in Diurnal Cliff-Nesting Raptor Occurrence on the Ungalik River in Western Alaska: 1977, 1979, and 2008 \\ Tim Craig ${ }^{1,2}$ and Erica H. Craig ${ }^{2}$
}

(Received 23 July 2015; accepted in revised form 24 February 2016)

\begin{abstract}
Diurnal cliff-nesting raptors were inventoried on the Ungalik River, Alaska, in 1977 and 1979. In 2008 we resurveyed the drainage, replicating the techniques used in 1979. The density of nesting raptors during the late nesting season has doubled in the past three decades, from six occupied territories detected in 1977 and four in 1979 to 12 in 2008. A single Peregrine Falcon (Falco peregrinus) was sighted during aerial surveys in 1977, and a pair of Peregrine Falcons was detected during a boat survey in 1979; however, nesting by these birds was not confirmed. In contrast, we detected five occupied Peregrine Falcon territories along the Ungalik River in 2008. Other changes in cliff-nesting raptor occurrence included a decrease in occupied Gyrfalcon (Falco rusticolus) territories from four in 1977 to one in 1979 and two in 2008, a decrease in Rough-legged Hawk (Buteo lagopus) nests from one in 1979 (none in 1977) to none in 2008, and increases in Golden Eagle (Aquila chrysaetos) nests, from two in 1977 and 1979 to five in 2008. Changes in the number of nests of cliff-nesting raptors in this small population may have resulted, in part, from natural variation associated with changes in weather or prey abundance. However, it is likely that the increase in nesting Peregrine Falcons is related to global population recovery. Our data indicate that factors other than available nesting sites limit cliff-nesting raptor numbers along the Ungalik River. Spatial analysis indicated that cliff-nesting raptor nests were most often on hills or cliffs that face away from the coast, which is the source of most storms.
\end{abstract}

Key words: Peregrine Falcon; Gyrfalcon; Golden Eagle; raptor survey; western Alaska

RÉSUMÉ. En 1977 et en 1979, des rapaces diurnes nichant en falaise ont été répertoriés sur la rivière Ungalik, en Alaska. En 2008, nous avons réalisé de nouveaux relevés dans le bassin hydrographique, en reprenant les techniques employées en 1979. La densité des nids de rapaces en fin de saison de nidification a doublé au cours des trois dernières décennies. En 1977, il y avait six territoires occupés, puis quatre en 1979, et 12 en 2008. Un seul faucon pèlerin (Falco peregrinus) a été vu durant les relevés aériens de 1977 et une paire de faucons pèlerins a été observée pendant un relevé en bateau en 1979, bien que la nidification de ces oiseaux n'ait pas été confirmée. En revanche, en 2008, nous avons observé cinq territoires de faucon pèlerin occupés le long de la rivière Ungalik. Parmi les autres changements dans l'occurrence des rapaces nichant en falaise, on compte une diminution des territoires de faucon gerfaut (Falco rusticolus) occupés, passant de quatre en 1977 à un en 1979, puis à deux, en 2008; une diminution des nids de buse pattue (Buteo lagopus), passant de un en 1979 (aucun en 1977) à aucun en 2008; une augmentation des nids d'aigle royal (Aquila chrysaetos), passant de deux en 1977 et en 1979 à cinq en 2008. Les changements caractérisant le nombre de nids de rapaces nichant en falaise dans cette petite population pourraient découler, en partie, de la variation naturelle liée aux changements climatiques ou de l'abondance des proies. Toutefois, il est probable que l'augmentation de faucons pèlerins en nidification soit liée au rétablissement de la population mondiale. Nos données indiquent que des facteurs autres que les sites de nidification disponibles limitent le nombre de rapaces diurnes nichant en falaise le long de la rivière Ungalik. Une analyse spatiale démontre que les rapaces diurnes nichant en falaise faisaient plus souvent leur nid sur les collines ou les falaises à l'opposé du littoral, d'où proviennent la plupart des tempêtes.

Mots clés : faucon pèlerin; faucon gerfaut; aigle royal; relevé des rapaces; ouest de l’Alaska

Traduit pour la revue Arctic par Nicole Giguère.

\section{INTRODUCTION}

In 1977 and 1979, raptor surveys were conducted along a number of rivers in western Alaska (White and Boyce, 1978; Robus et al., 1979). The lands surveyed were subject to changes in management or ownership, or both, under terms of the Alaska Native Claims Settlement Act (43 U.S. Code, Chapter 33; White and Boyce, 1978). At that time, the Peregrine Falcon (Falco peregrinus) was listed as "Endangered" under the Endangered Species Act (1973). The main

\footnotetext{
${ }^{1}$ Corresponding author: Bureau of Land Management, 1150 University Avenue, Fairbanks, Alaska 99709, USA; t0pkat1951@gmail.com

${ }^{2}$ Present address: Aquila Environmental, PO Box 81291, Fairbanks, Alaska 99708, USA

(C) The Arctic Institute of North America
} 
purpose of the surveys was to determine whether nesting Peregrine Falcons were present on these lands, but few nests were located. Peregrine Falcons were observed in the Ungalik River drainage during both surveys (a single bird in 1977, and a pair in 1979), although their nesting status was not confirmed. Nonetheless, White and Boyce (1978) thought that of all the rivers they surveyed in the Norton Bay area, the Ungalik River held the most suitable potential habitat for Peregrine Falcons.

The early surveyors recorded all of the diurnal cliffnesting raptors they encountered in western Alaska, and from these records they produced an ecological profile of raptor habitat use along the rivers they surveyed. White and Boyce (1978) found that the Ungalik River had the highest cliff-nesting raptor population of any of the rivers they surveyed; the species they encountered included Golden Eagles (Aquila chrysaetos), Gyrfalcons (Falco rusticolus), and Rough-legged Hawks (Buteo lagopus), along with a single Peregrine Falcon.

Ultimately, most of the lands in the Ungalik River drainage remained under federal management by the Bureau of Land Management (BLM), and the Peregrine Falcon was delisted in 1999 (Mesta, 1999). The effect of delisting was relaxation of protected status for the species. Nonetheless, federal agencies in Alaska still continue to conduct surveys of raptors and other wildlife resources on lands they manage. In particular, the BLM is mandated to inventory and monitor resources on BLM lands under the Federal Land Policy and Management Act (Olendorff et al., 1989; Olendorff and Kochert, 1992) and to fulfill their obligations under the National Environmental Policy Act, the Migratory Bird Treaty Act, and the Bald and Golden Eagle Protection Act.

To our knowledge, the only historical inventories of raptors on the Ungalik River took place in 1977 (White and Boyce, 1978) and 1979 (Robus et al., 1979). In summer 2008, we resurveyed the Ungalik River, replicating the techniques used in the 1979 raft survey. We had three specific objectives: 1) to determine whether Peregrine Falcons nested in the drainage; 2) to compare the current numbers, species composition, and distribution of diurnal cliffnesting raptors with findings from the earlier surveys; and 3) to identify parameters that characterize raptor distribution along the Ungalik River using Geographic Information System (GIS) analyses.

\section{STUDY AREA}

The Ungalik River in western Alaska flows westward out of the Nulato Hills into Norton Bay. Elevations along the river range from $\sim 214 \mathrm{~m}$ at the point where we began surveying to $\sim 124 \mathrm{~m}$ at our end location near the coastal plain. The physiography changes as the river descends toward the coast. The upper reaches of the drainage are mountainous, with numerous cliffs bordering the river, while the terrain near the coastal plain is gentler and has fewer escarpments. Vegetation along the Ungalik River ranges from coniferous forest at higher elevations to shrub thickets and more open habitats like meadows at the lower elevations (Kessel, 1979; Gallant et al., 1995).

\section{METHODS}

Most of the Ungalik River was surveyed by wildlife biologists from fixed-wing aircraft and helicopter in 1977 $(\sim 90 \mathrm{~km})$ and from a non-motorized raft in $1979(\sim 99 \mathrm{~km})$. We attempted to replicate the 1979 raft survey in 2008. The 1979 survey began at approximately river kilometer (RK) 112 and ended at $\sim$ RK 13. For logistical reasons, we departed from the 1979 survey method in 2008 by beginning our survey at $\sim$ RK 110 and using a helicopter to survey the last $8 \mathrm{~km}$ of the $\sim 97 \mathrm{~km}$ river survey route.

Like the 1979 raft survey, our inventory was conducted during the late nestling stage for Peregrine Falcons (15-21 July, when young were about 30 days old). Golden Eagles and Gyrfalcons nest earlier than Peregrine Falcons in that area, and their young were commensurately older during our survey; in fact, at some nests young had already fledged and were perched on cliffs near their nest sites.

Current raptor survey protocols, like the Monitoring Plan for the American Peregrine Falcon (U.S. Fish and Wildlife Service, 2003), specify that multiple visits be made to potential nesting cliffs and that surveyors remain at each cliff for several hours to validate "no occupancy" when birds are not observed. However, the earlier surveys of the Ungalik drainage predated these protocols. During the 2008 survey, we endeavored to recreate the methods used during the 1979 raft survey so that our results would be comparable. The 1979 surveyors recorded on maps all potential nesting cliffs for raptors that they found (Robus et al., 1979). Like them, we searched for raptors or evidence of raptor activity (e.g., fresh feces at perch sites) at each of these potential nesting cliffs, and we moved on only when satisfied that we had determined whether the cliff was occupied by raptors.

Following terminology established in Steenhof and Newton (2007), we considered an area to be an occupied nesting territory (Occupied Territory) if we or the earlier surveyors observed 1) one or more adult raptors or a mixed pair (adult + subadult) that exhibited an affinity to a cliff (e.g., territorial defense, nesting behavior); 2) nestlings or recently fledged young at a cliff; or 3) evidence at a vacant nest of occupation during the current nesting season by raptors (e.g., feces, molted feathers, fresh greenery, fresh prey remains). We defined a "Raptor-used Cliff" as one where we observed evidence that raptors had nested there in past seasons (e.g., an old stick nest), or where raptors had obviously used a cliff in the current season (e.g., fresh feces), but where no nest was present. "Available Cliffs" are those identified in the 1979 raft survey as potential raptor nesting sites.

We made no assessment of the prey resources available to raptors during our survey, nor did any of the earlier Ungalik River surveyors. 


\section{Data Analysis}

We recorded locations on a Garmin eTREX Vista GPS unit (geographic coordinate system WGS84) and imported these data into GIS for analysis using DNR Garmin software (version 5.1.1, Minnesota Dept. of Natural Resources, St. Paul, MN). In the earlier surveys, data were recorded directly on 1:63 000 scale paper maps, in field notes, or both. We transposed those historical data onto maps in the GIS environment for spatial evaluation. We manipulated data in GIS using ArcMapTM 9.2 (ESRI Inc. Redland, CA; projection: Alaska Albers Equal Area Conical, North American Datum 1983) and Hawth's Tools (Beyer, 2004). We calculated nearest neighbor distances in ArcMap. A pair of Peregrine Falcons had been observed during the 1979 survey; however, we did not include them in the nearest neighbor analysis for that year because their nesting status was not confirmed.

Resolution of the raster data sets was $30 \mathrm{~m}$. In ArcMap, we created five digital layers of the study area: hydrology (National Hydrologic Dataset; USGS National Map), surficial geology (Karlstrom, 1964), digital elevation model (DEM; National Elevation Dataset; USGS), aspect (derived from the DEM), and vegetation cover (Homer et al., 2004). We generated random points $(n=949)$ within $1 \mathrm{~km}$ of either side of the river centerline for comparison to nest and cliff locations. Data from the layers were extracted to the nest and cliff locations and to the random locations for statistical analysis. We compared vegetation cover within a $1 \mathrm{~km}$ radius buffer around Raptor-used Cliffs, Available Cliffs, Occupied Territories, and the random points.

We derived the general aspect of cliffs from field records or from topographic maps. Therefore, our data represent the major orientation of the cliff or hillside on which a nest was located (along with the slope exposure of one Golden Eagle nest that was in a tree), not the specific microsite where the nest itself was located. The following five categories were used for analysis of aspect: North $=315^{\circ}-44^{\circ}$; East $=$ $45^{\circ}-134^{\circ}$; South $=135^{\circ}-224^{\circ}$; West $=225^{\circ}-314^{\circ}$; Flat $=$ no aspect.

All statistical tests were calculated using $\alpha=0.05$. We used chi-squared goodness of fit for comparative analyses (R Core Team, 2013 [chisq.test in R]). Vegetation categories that were poorly represented $(<1.0 \%)$ were combined with other categories for analysis.

\section{RESULTS AND DISCUSSION}

We found 12 Occupied Territories of diurnal, cliffnesting raptors (1 Occupied Territory $/ 8.1 \mathrm{~km}$ ) and sighted four additional cliff-nesters that did not exhibit territorial behavior during our survey (Table 1; Fig. 1). The 1977 and 1979 surveys had reported about half as many: 1 Occupied Territory/15.0 km in the 1977 aerial surveys and 1 Occupied Territory/24.8 km in the 1979 raft survey (White and Boyce, 1978; Robus et al., 1979). The different findings of the 1977
TABLE 1. Number of Occupied Territories of diurnal cliff-nesting raptors located during surveys on the Ungalik River, Alaska, in 1977, 1979, and 2008. Observations of cliff-nesting raptors not associated with a territory are indicated in parentheses.

\begin{tabular}{lccc}
\hline \hline Species & 1977 & 1979 & 2008 \\
\hline Gyrfalcon & 4 & $1(1)$ & 2 \\
Peregrine Falcon & $0(1)$ & $0(1)^{1}$ & $5(3)$ \\
Golden Eagle & 2 & 2 & $5(1)$ \\
Rough-legged Hawk & $0^{2}$ & $1(1)$ & 0 \\
Total Occupied Territories & 6 & 4 & 12 \\
\hline \hline
\end{tabular}

${ }^{1}$ A pair of Peregrine Falcons was noted on the original 1979 field maps, but nesting status was not confirmed in the field notes.

${ }^{2}$ Three nests constructed by Rough-legged Hawks were observed in the 1977 survey, but territory occupancy was not confirmed.

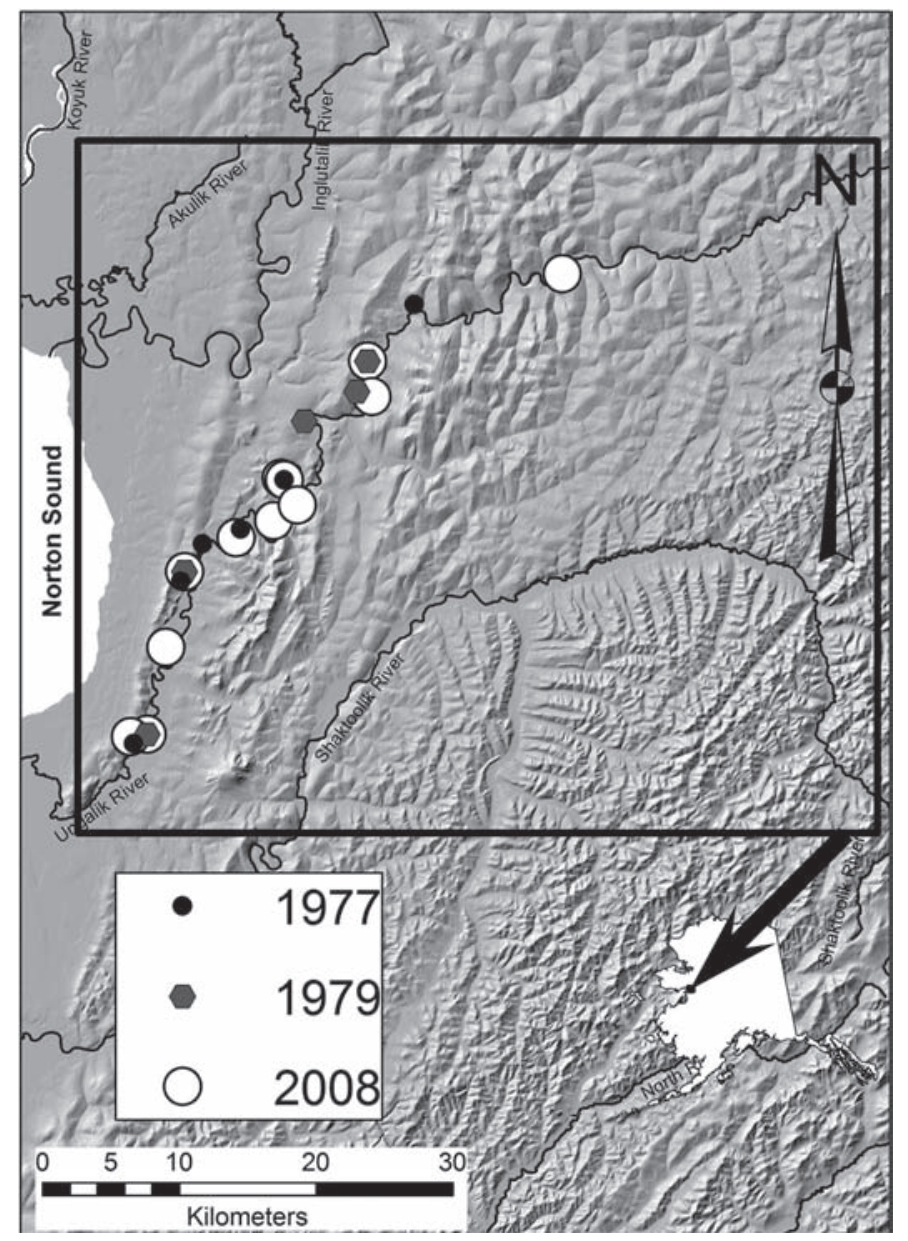

FIG. 1. Locations of Occupied Territories of diurnal cliff-nesting raptors recorded during surveys on the Ungalik River, Alaska, in 1977, 1979, and 2008. The map includes the location of a pair of Peregrine Falcons sighted in 1979 but for which nesting status was not confirmed.

and 1979 surveys may have resulted from differences in the detection rates of the two survey techniques.

The mean nearest-neighbor distance between Occupied Territories along the Ungalik River in 2008 reflects 
TABLE 2. Comparison of nearest-neighbor distances $(\mathrm{km})$ for Occupied Territories of diurnal cliff-nesting raptors, Raptor-used cliffs, and Available Cliffs along the Ungalik River, Alaska. Mean, minimum, and maximum distances are shown, with standard errors in parentheses.

\begin{tabular}{|c|c|c|c|c|c|}
\hline \multirow[b]{2}{*}{ Parameter } & \multirow[b]{2}{*}{$\begin{array}{l}\text { Available cliffs } \\
\quad(\mathrm{n}=14)\end{array}$} & \multirow[b]{2}{*}{$\begin{array}{l}\text { Raptor-used cliffs } \\
\qquad(\mathrm{n}=31)\end{array}$} & \multicolumn{3}{|c|}{ Occupied territories } \\
\hline & & & $\begin{array}{l}1977 \\
(\mathrm{n}=6)\end{array}$ & $\begin{array}{c}1979 \\
(\mathrm{n}=4)\end{array}$ & $\begin{array}{c}2008 \\
(\mathrm{n}=12)\end{array}$ \\
\hline Mean distance to nearest neighbor & $1.4(0.8)$ & $1.3(0.6)$ & $7.0(5.2)$ & $8.7(5.7)$ & $3.4(1.2)$ \\
\hline Minimum distance to neighbor & 0.7 & 0.7 & 3.0 & 2.4 & 0.3 \\
\hline Maximum distance to neighbor & 3.6 & 2.7 & 16.0 & 25.6 & 15.6 \\
\hline
\end{tabular}

the increased number of nesting raptors we found; it was less than half the distances found during the 1977 and 1979 surveys (Table 2). The shortest nearest-neighbor distance found in $2008(0.3 \mathrm{~km})$ was between a Peregrine Falcon nest containing three downy nestlings and a Golden Eagle stick nest. The Golden Eagle nest contained freshly molted eagle feathers but no nestlings and appeared to have failed early in the nesting season.

We found more Golden Eagle and Peregrine Falcon nests along the Ungalik River than were found on either earlier survey, but fewer Gyrfalcon and Rough-legged Hawk nests. Unfortunately, the raptor population in the drainage is too small to allow statistical comparisons among years. Nonetheless, it is interesting to note that:

- none of the six territories recorded as occupied by cliffnesting raptors in 1977 were on the same cliffs occupied by nesting raptors in 1979;

- one of the occupied Golden Eagle territories recorded in 1977 and two others recorded in 1979 were on the same nest cliffs that nesting Golden Eagles occupied in 2008;

- a cliff with an occupied Gyrfalcon territory in 1977 was occupied by nesting Peregrine Falcons in 2008;

- the cliff occupied by a nesting Rough-legged Hawk in 1979 was occupied by a Great Horned Owl (Bubo virginianus) in 2008;

- In 2008, Peregrine Falcons occupied a cliff where a pair of Peregrine Falcons had been sighted in 1979.

Only one pair of Peregrine Falcons was seen during the early surveys of the Ungalik River, and their nesting status was not confirmed. In contrast, we found five Occupied Territories in 2008. The Arctic and Subarctic populations of Peregrine Falcons underwent dramatic reductions in the past resulting from the widespread use of organochlorine pesticides (Green et al., 2006). Our findings, like those of others (Ritchie and Shook, 2011), probably reflect the overall recovery of Peregrine Falcon populations in the United States (White et al., 2002). Since all of the surveys on the Ungalik River were conducted late in the nesting season, they may not have detected some nesting attempts that failed earlier in the season (Steenhof and Kochert, 1982). Therefore, it is likely that the Occupied Territories that we and others observed did not reflect the total number of such territories located along the river during survey years.
Diurnal cliff-nesting raptors occupied only $14.6 \%$ of the 41 Available Cliffs along the Ungalik River in 1977 and $10.3 \%$ in 1979 . We found twice as many Occupied Territories in $2008(29.3 \%)$, along with evidence that raptors had used $75.6 \%$ (31) of the Available Cliffs. In addition, we found 17 vacant stick nests that were probably built by either raptors or Common Ravens (Corvus corax) on 12 different cliffs along the river, as well as multiple potential nest ledges that were vacant. Gyrfalcons and Peregrine Falcons do not build their own nests; like Golden Eagles, they sometimes nest on substrates other than cliffs (Kochert et al., 2002; White et al., 2002; Booms et al., 2008). The nest sites selected by Peregrine Falcons are particularly variable; this species is known to nest on sheer cliffs of varying heights (both in natural sites and in old stick nests of other birds), on bluffs or man-made structures, in tree nests made by other birds (White et al., 2002), and even on the ground (Ellis et al., 2009). However, with the exception of one Golden Eagle nest, which was located in the top of a large white spruce tree (Picea glauca), all of the occupied diurnal cliff-nesting raptor nests that we located were on cliffs or bluffs along the river. Therefore, the number of available nest sites for cliff-nesting raptors is not likely a limiting factor in the Ungalik drainage.

It has been documented that the distribution of breeding raptors is influenced by availability of both prey (Newton, 1979) and suitable nest sites (Wightman and Fuller, 2006). The fact that some of the same cliffs along the Ungalik River were still being used almost three decades after the first surveys suggests that the quality of the environment, at least at these nesting territories, remains suitable for nesting raptors. Additional factors, such as territorial defense, avoidance of dominant raptor species, and resource depression within the home range of breeding raptors may also contribute to spacing of raptor territories (e.g., Newton, 1979; Nilsson et al., 1982; Ratcliffe, 1993; Gainzarain et al., 2000). Any of these factors could influence the spacing and distribution of raptor nests on the Ungalik River.

When we compared the locations of Occupied Territories for the three survey years to the randomly distributed points, we found that the difference between habitats that were available along the entire river and those within $1 \mathrm{~km}$ of Occupied Territories was highly significant $\left(\chi_{\text {calc }}^{2}=86.3\right.$; $\mathrm{df}=5 ; p<0.00$; Fig. 2). The nest sites occurred more often than expected in shrub or scrub habitats and less often than expected in sedge or herbaceous habitats. A similar pattern 


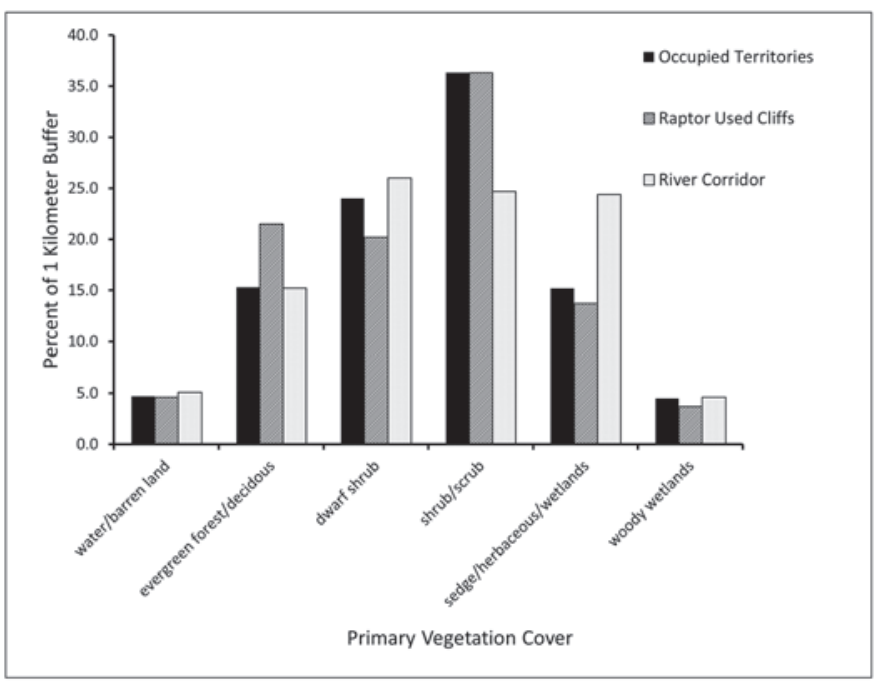

FIG. 2. Comparison of vegetation communities along the Ungalik River, Alaska, that occur in a $1 \mathrm{~km}$ buffered radius surrounding Occupied Territories of diurnal cliff-nesting raptors (1977, 1979, 2008), all Raptor-used cliffs, and the River Corridor. The difference in frequency distributions of vegetation communities between Occupied Territories and the River Corridor is significant $(p<0.00)$

holds for surficial geology (after Karlstrom, 1964): Occupied Nest Sites or Raptor-used cliffs were located more often than randomly distributed points $(77.4 \%$ vs. $60.1 \%$ of locations) in areas of coarse and fine rubble, typical of cliffy areas. Although this difference was not statistically significant $\left(\chi^{2}=3.9890, \mathrm{df}=2, p>0.05\right)$, these data, along with other habitat preferences, may be useful for predictive modeling when designing future raptor inventories in remote areas of western Alaska.

Most of the cliffs with occupied raptor nests on the Ungalik River faced east, and they were least likely to face south. Our sample sizes were too small for statistical comparisons; however, we note that the percentage of nest sites on east-facing cliffs ( $>60 \%$ ) was higher than the percentage of Available Cliffs that faced east (ca. 40\%), as shown in Figure 3. In contrast, other studies (Craig and Craig, 1984; Ritchie and Shook, 2011) have found that cliff-nesting raptors at high elevations or in northern climates tend to select nest sites that face south, or nearly so. Although southfacing cliffs were available along the Ungalik River, raptors predominantly used those with eastern exposures. This choice may be related to local weather patterns. Storms typically arise in Norton Bay and travel inland to the east. Wightman and Fuller (2006) also reported that raptors may select nest sites that are protected from inclement weather.

\section{SUMMARY}

The number of nesting raptors observed on the Ungalik River has doubled in the past three decades. However, their density is still relatively low: not quite one-third of the Available Cliffs were occupied by nesting raptors during our survey. Factors other than available nesting sites limit

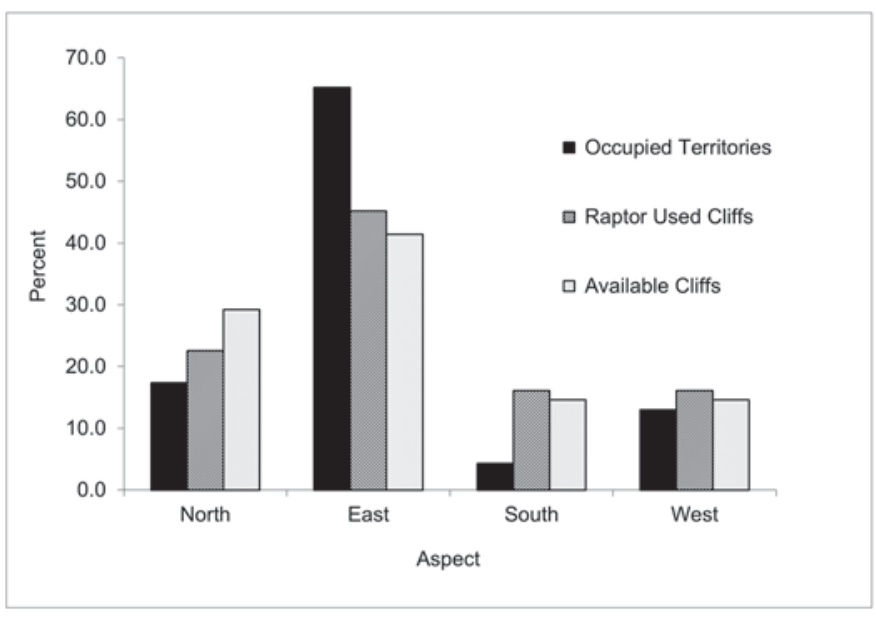

FIG. 3. General aspect of Occupied Territories of diurnal cliff-nesting raptors compared to Available Cliffs and Raptor-used cliffs on the Ungalik River, Alaska. A single Golden Eagle nest located in a spruce tree on an east-facing slope was included in this analysis.

the number of cliff-nesting raptors along this river. Spatial analysis of the data for all years indicates that cliff-nesters were found most often in shrub or scrub habitats associated with the coarse and fine rubble typical of cliffs and rocky outcrops, especially on hills or cliffs facing away from the coast, where severe weather often originates.

Raptor territories that are occupied in the spring, but fail early, are rarely detected later in the nesting season. Because all three surveys along the Ungalik River were conducted during the late nestling stage, the total population of cliff-nesting raptors on the Ungalik River is probably somewhat higher than reported here.

\section{ACKNOWLEDGEMENTS}

We thank B. Ritchie and two anonymous reviewers who made valuable suggestions during evaluation of this paper. This project was funded by the Fairbanks District Office of the Bureau of Land Management, Fairbanks, Alaska. We would like to thank BLM staff who supported our survey and Kyle Joly of the National Park Service who helped us with logistics during the work.

\section{REFERENCES}

Beyer, H.L. 2004. Hawth's analysis tools for ArcGIS, Version 3.27.

http://www.spatialecology.com/htools

Booms, T.L., Cade, T.J., and Clum, N.J. 2008. Gyrfalcon (Falco rusticolus). In: Poole, A., ed. The birds of North America Online. Ithaca, New York: Cornell Lab of Ornithology. http://bna.birds.cornell.edu/bna/species/114

Craig, T.H., and Craig, E.H. 1984. Results of a helicopter survey of cliff nesting raptors in a deep canyon in southern Idaho. Journal of Raptor Research 18(1):20-25. 
Ellis, D.H., Craig, T., Craig, E., Postupalsky, S., LaRue, C.T., Nelson, R.W., Anderson, D.W., et al. 2009. Unusual raptor nests around the world. Journal of Raptor Research 43(3):175 - 198. http://dx.doi.org/10.3356/JRR-08-110.1

Gainzarain, J.A., Arambarri, R., and Rodríguez, A.F. 2000. Breeding density, habitat selection and reproductive rates of the Peregrine Falcon Falco peregrinus in Álava (northern Spain). Bird Study 47(2):225-231. http://dx.doi.org/10.1080/00063650009461177

Gallant, A.L., Binnian, E.F., Omernik, J.M., and Shasby, M.B. 1995. Ecoregions of Alaska. U.S. Geological Survey Professional Paper No. 1567. Washington, D.C.: U.S. Government Printing Office.

Green, M., Swem, T., Morin, M., Mesta, R., Klee, M., Hollar, K., Hazlewood, R., Delphey, P., Currie, R., and Amaral, M. 2006. Monitoring results for breeding American Peregrine Falcons (Falco peregrinus anatum), 2003. Biological Technical Publication BTP-R1005-2006, Washington, D.C.: U.S. Fish and Wildlife Service.

Homer, C., Huang, C., Yang, L., Wylie, B., and Coan, M. 2004. Development of a 2001 national land-cover database for the United States. Photogrammetric Engineering \& Remote Sensing 70:829-840. http://dx.doi.org/10.14358/PERS.70.7.829

Karlstrom, T.N.V. 1964. Surficial geology of Alaska. U.S. Geological Survey Miscellaneous Geologic Investigations Series Map 357, 2 sheets, scale 1:1,584,000.

Kessel, B. 1979. Avian habitat classification for Alaska. The Murrelet 60(3):86-94. http://dx.doi.org/10.2307/3534270

Kochert, M.N., Steenhof, K., Mcintyre, C.L., and Craig, E.H. 2002. Golden Eagle (Aquila chrysaetos). In: Poole, A., ed. The birds of North America Online. Ithaca, New York: Cornell Lab of Ornithology.

http://bna.birds.cornell.edu/bna/species/684

Mesta, R. 1999. Final rule to remove the American Peregrine Falcon from the Federal List of Endangered and Threatened Wildlife, and to remove the similarity of appearance provision for free-flying peregrines in the conterminous United States. Federal Register 64(164):46542-46558.

Newton, I. 1979. Population ecology of raptors. Vermillion, South Dakota: Buteo Books.

Nilsson, I.N., Nilsson, S.G., and Sylvén, M. 1982. Diet choice, resource depression, and the regular nest spacing of birds of prey. Biological Journal of the Linnean Society 18(1):1-9. http://dx.doi.org/10.1111/j.1095-8312.1982.tb02030.x

Olendorff, R.R., and Kochert, M.N. 1992. Raptor habitat management on public lands: A strategy for the future. Washington, D.C.: U.S. Department of the Interior, Bureau of Land Management.
Olendorff, R.R., Bibles, D.D., Dean, M.T., Haugh, J.R., and Kochert, M.N. 1989. Raptor habitat management under the U.S. Bureau of Land Management multiple-use mandate. Raptor Research Reports 8.80 p.

Ratcliffe, D. 1993. The Peregrine Falcon, 2nd ed. London: T. \& A.D. Poyser.

R Core Team. 2013. R: A language and environment for statistical computing. Vienna, Austria: R Foundation for Statistical Computing. http://www.R-project.org/

Ritchie, R.J., and Shook, J.E. 2011. Recovery and trends of Peregrine Falcons breeding in the Yukon-Tanana Uplands, east-central Alaska, 1995-2003. Journal of Raptor Research 45(2):150-159. http://dx.doi.org/10.3356/JRR-09-13.1

Robus, M., Durtsche, B., Gipson P., and McLean, L.S. 1979. Unpubl. field maps/notes. Available at U.S. Department of Interior, Bureau of Land Management, Fairbanks District Office, Fairbanks, Alaska 99701.

Steenhof, K., and Kochert, M.N. 1982. An evaluation of methods used to estimate raptor nesting success. Journal of Wildlife Management 46(4):885-893.

http://dx.doi.org/10.2307/3808221

Steenhof, K., and Newton, I. 2007. Assessing nesting success and productivity. In: Bird, D.M., and Bildstein, K.L., eds. Raptor research and management techniques. Surrey, British Columbia: Hancock House. 181-192.

U.S. Fish and Wildlife Service. 2003. Monitoring plan for the American Peregrine Falcon: A species recovered under the Endangered Species Act. Portland, Oregon: U.S. Fish and Wildlife Service, Divisions of Endangered Species and Migratory Birds and State Programs, Pacific Region. 53 p.

White, C.M., and Boyce, D.A. 1978. A profile of various rivers and their raptor populations in western Alaska 1977. BLM/ AK/TR/78/01. Anchorage: Bureau of Land Management.

White, C.M., Clum, N.J., Cade, T.J., and Hunt, W.G. 2002. Peregrine Falcon (Falco peregrinus). In: Poole, A., ed. The birds of North America Online. Ithaca, New York: Cornell Lab of Ornithology. http://bna.birds.cornell.edu/bna/species/660

Wightman, C.S., and Fuller, M.R. 2006. Influence of habitat heterogeneity on distribution, occupancy patterns, and productivity of breeding Peregrine Falcons in central West Greenland. The Condor 108(2):270-281. http://dx.doi.org/10.1650/0010-5422(2006)108[270:IOHHOD]2 .0. $\mathrm{CO} ; 2$ 